\title{
HeLPINg SOUTH AfRICANS ACHIEve A BetTER INCOME IN RETIREMENT: A CRITICAL EVALUATION OF THE IMPACT OF TREASURY PROPOSALS
}

\author{
Jesse de Beer* \\ University of the Free State \\ DeBeerJA@ufs.ac.za
}

Received: July 2013

Accepted: August 2014

\begin{abstract}
Retirement income security is an issue relevant to the majority of South Africans, many of whom are financially inexperienced and illiterate. South Africa has a sophisticated retirement industry offering a very wide range of choice of annuity products, but these are often not designed to optimise choices by rather unsophisticated investors. This article provides an overview of issues in the South African income withdrawal market, as well as policy remedies proposed by National Treasury to deal with these issues. The aim of this paper is to provide a critical analysis of these policy proposals, using a behaviourally informed framework to financial regulation (Barr, Mullainathan \& Shafir, 2008). It recognises that policy remedies need to take into account the realities of how people make retirement income decisions, and how the institutional environment impacts on this. The results of the research suggest that the main policy proposal - simplifying the retirement income withdrawal landscape through the use of default options - is only a partial solution to the problem of unsophisticated consumers who must make several challenging decisions. The research contributes to the literature by providing a more complete, integrated view of the factors that shape retirement income withdrawal decisions and offers practitioners several insights into appropriate reform of the retirement income market.
\end{abstract}

Keywords

Retirement planning, behavioural economics, choice architecture

*Dr JA de Beer is a senior lecturer in the Department of Economics, University of the Free State, Bloemfontein, South Africa. 


\section{INTRODUCTION}

South African retirees face increasing responsibility for their financial security in a challenging environment. Most South Africans will face financial insecurity in retirement - as illustrated in a National Treasury (2012) statement that only about $10 \%$ of South Africans will be able to maintain their pre-retirement living standards in retirement. How to make a multitude of challenging interrelated choices and how to convert accumulated retirement savings into a regular income is a major part of the challenge of retirement income security. Indeed, the literature shows that most retirees are ill-equipped to make these decisions (Tapia \& Yermo, 2007; Agnew, Anderson \& Szykman, 2011).

Improving the financial security of South Africans in retirement is the main aim of a number of consultation documents on retirement reforms in South Africa, the first of which was published in 2004 (National Treasury, 2004). Since then, the debate on the appropriate nature of such reforms has evolved considerably. This article focuses specifically on the proposal contained in the document "Enabling a better income in retirement" released in 2012 (National Treasury, 2012). This document outlines the range of retirement income withdrawal products in the South African context, the challenges as perceived by Treasury, and the proposed policy remedies.

Designing effective policy interventions to help people better manage their income in retirement requires a deep understanding of how people make financial choices. This can enhance understanding of areas of poor management of income withdrawal. Consequently, it can guide policy proposals aimed at increasing retirement income security. The behavioural economics literature has gained prominence in this regard in the recent past (Benartzi, Previtero \& Thaler, 2011; Oehler, Kohlert \& Jungermann, 2010; Thaler \& Sunstein, 2008).

Although several recent academic papers have discussed the implications of behavioural economics for policy, most of these papers are rather general in scope and do not address several aspects that are crucial to retirement income security in South Africa, the subject of this article (Tapia \& Yermo, 2007; Oehler, Kohlert \& Jungermann 2010). For example, most of these studies focus on the sub-optimal nature of investment decisions, with little reference to policy remedies and even fewer references to the limitations of policy prescriptions based on behavioural economics principles.

The decumulation phase of retirement income planning has also received relatively little attention in the literature (MacDonald et al., 2012). Although the importance of the decumulation phase is increasingly recognised in the literature, there is still very little known about optimal drawdown strategies or actual strategies used by retirees (Brown, 2009). The available evidence suggests sub-optimal spending decisions in retirement (Poterba, Venti \& Wise, 2011). US survey evidence suggests a complete lack of systematic drawdown strategies (Greenwald et al., 2006). Finally, most existing studies have been written from a developed world perspective.

While international literature on the decumulation phase of income retirement planning is limited, South African evidence is almost non-existent. For example, there is no systematic empirical evidence on the income withdrawal strategies used by South African pensioners. Instead, the debate centres on the level and sustainability of living annuity drawdown rates and the cost structure of living annuities. Thus, there is plenty of scope for more research on the factors that influence the retirement income decisions of South Africans, and this paper is an important starting point to a more nuanced debate. 
The aim of this article is to provide a critical analysis of the main policy proposals contained in the 2012 National Treasury document on retirement income reform. The proposal will be evaluated against insights from the behavioural economics literature on how people actually make financial decisions. It recognises that policy remedies need to take into account the realities of how people make retirement income decisions, and how the institutional environment affects these decisions. If remedies do not address these issues, then pension reform proposals will not have the desired effect, and retirement income security will remain an elusive goal.

The article is organised as follows: section two provides an overview of the retirement landscape in South Africa. Existing evidence on the (lack of) retirement security of South Africans is cited. Section three provides a critical evaluation of some policy options to increase retirement income security in South Africa. Four main policy proposals are discussed, namely, placing limits on consumer choice, increasing the degree of automation in the retirement process, increasing the degree of longevity protection for most retirees, and limiting the need for financial advice and financial intermediation. This includes an evaluation of pension reform proposals in the light of lessons learned from the academic literature and suggests certain policy remedies that are not considered in the discussion documents. The rationale for each policy proposal is discussed and then evaluated in terms of the available academic literature. The focus is both on individual decision-making and the implications of behavioural economics research for policy initiatives. A behaviourally informed framework to financial regulation (Barr et al., 2008) is utilised. Such a framework considers the effect of individual psychology on investor decisions, but also the effect of firm incentives to respond to regulation. The notion that financial education and products and regulations that address behavioural biases may be seen as a set of complementary tools will be considered. The last section concludes and contains suggestions for further research.

\section{BACKGROUND: THE NATURE OF THE INCOME DRAWDOWN MARKET AND ISSUES IN THE SOUTH AFRICAN INCOME WITHDRAWAL MARKET}

There is world-wide concern about exceedingly complex financial systems that are often not designed to optimise choices by and behaviour of somewhat unsophisticated investors. This is also the case in South Africa, as the country has a sophisticated retirement industry offering a very wide range of annuity products (National Treasury, 2012). The majority of South African pension fund plans are defined contribution plans. In principle, such a system offers the potential to create individually tailored pension plans and facilitate individual decisionmaking. However, in practice, the wide array of financial products to choose from, and the shift of more responsibility and risk towards the individual, can manifest in choice paralysis and suboptimal decisions (Beshears et al., 2008; Merton, 2003).

At retirement, South Africans are mandated to purchase some kind of annuity with two-thirds of their accumulated retirement savings. The main choice is to decide between living annuities or conventional annuities. Living annuities are essentially investment accounts provided by life insurance companies and offer investors several choices, such as how much income to draw down, what underlying assets to invest in and which provider to choose. As such, they are contracts geared to the needs of the relatively wealthy and individuals who have a fair degree of financial knowledge, and are generally not appropriate if the retirement amount is not very large and if the pensioner is completely dependent on the income. Conventional annuities, on the 
other hand, offer an income for life, determined at time of purchase. The decision to buy a conventional annuity is irreversible. In contrast to the living annuity, no decisions are required from the annuitant once the annuity is purchased. Living annuities are by far the more popular choice. By value, conventional annuities constituted only about $14 \%$ of the total annuity market in 2011 (down from 50\% in 2003) and $20 \%$ by number of policies (down from about $65 \%$ in 2007).

This shift away from conventional annuities towards living annuities underlies many of the concerns identified as major problems in the South African retirement income landscape. Annuity purchase behaviour appears to be driven strongly by short-term considerations, such as opting for high initial income or drawdown rates. The data indicates median policy drawdown rates of $7.5 \%$ per year before charges, estimated to be $10 \%$ after charges (ASISA IIla survey, 2012; Alexander Forbes, 2013). Given the assumption of a $5 \%$ sustainable drawdown rate (ASISA, 2012), drawdown rates at this level expose purchasers to substantial risks of declining real income. The retirement security of members with lower living annuity balances is a major concern. Pensioners who are drawing between $17.5 \%$ and $20 \%$ of their balances receive an average monthly pension of only $\mathrm{Rl} 640$.

In addition to concerns about unsustainable drawdown rates, the high cost structures of living annuities and consequently potential misselling of living annuities are the major problems in the South African retirement income landscape. (National Treasury, 2012). Misselling concerns stem from perceived distortions in the distribution channels, most notably a commission structure that appears to give financial intermediaries substantial incentives to drive individuals into living, rather than conventional annuities.

\section{PROPOSED POLICY REMEDIES TO IMPROVE THE SOUTH AFRICAN RETIREMENT INCOME WITHDRAWAL MARKET}

\subsection{Policy proposal: Placing limits on consumer choice}

Limiting the choices retirees need to make when choosing income drawdown products, and the costs associated with their investment choice, are the main policy proposals put forward by National Treasury to deal with the problems mentioned above in order to ensure better incomes in retirement. The proposed default post-retirement solution would also minimise the need for advice and regulates intermediary fees. The goal is to secure a minimum income for life.

These proposals will be critically evaluated herein. The critical analysis is based on the principles of behaviourally informed regulation (Barr et al., 2008). This emphasises the need to take into account not only the consumer's behaviour, but also the incentives for financial institution agents. Another guiding principle in the evaluation of the policy proposal is that regulators need to know the nature of consumers' investment skills, knowledge, and behaviour to help them make better decisions (Black, 2006).

\subsubsection{The rationale for the policy decision: the role of choice in financial decision- making}

The current structure of living annuities offers South African retirees extensive choice in terms of the product provider, composition of the underlying portfolio, and the desired withdrawal rate. According to the National Treasury, this extensive choice is the major reason for the high living annuity policy charges. Consequently, the main proposed policy remedy is to limit the number 
and the extent of income retirement product choices that people need to make. National Treasury further justifies this policy proposal on the basis that the majority of South Africans simply choose not to use the multitude of choices available to them, as evidenced by the fact that many living annuities appear to be invested in similar underlying portfolios (National Treasury, 2012: 19).

This policy proposal is in line with the international behavioural economics literature that suggests that most investors are ill-equipped to make these choices. This is an even more pressing concern in the South African context, given the fact that the majority of South Africans are financially naive and illiterate (Atkinson \& Messy, 2012; Japelli, 2010). The problem of low financial literacy applies to all demographic groups in South Africa, but is especially pressing among lower-income groups in rural areas (Collins, 2007).

Extensive choice is regarded as a positive feature for consumers in mainstream economic thought. More choice automatically translates into greater overall utility, given that individuals have well-defined and consistent preferences. They also have access to sufficient information to enable them to effectively assess the costs and benefits of each option, and will act in ways that maximise their own 'utility' (Fear, 2008).

The reality of choice in the realm of retirement income products is starkly different: they are choices based on lack of information and no clear preferences. Coupled with product complexity, it implies that people are often presented with choices that they would prefer not to make, or prefer someone else to make on their behalf (Fear, 2008; lyengar \& Kamenica, 2006).

The inherently risky nature of retirement income products makes consumer decisions particularly prone to bias and errors. Decisions such as investing in a conventional annuity may be critical and irreversible. Most people are unfamiliar with the nature and consequences of retirement income products. Retirement income product decisions are made even more complex by the interaction of individual needs, family needs, state benefits and taxation, and by uncertainties regarding health and longevity. The volatility of financial markets and the risk of poor investment returns further complicate retirement income decisions. For a substantial segment of people, this task may be so daunting and discouraging that they rely on decision heuristics that simplify decision-making, but may not necessarily produce appropriate outcomes.

The behavioural finance literature contains several findings that point to the fact that retirees find it difficult to make optimal retirement income decisions. For example, the tendency to pay too much attention to irrelevant information and too little attention to relevant information is an important obstacle to optimal decisions concerning product providers. This includes chasing past returns in asset allocation choices while paying too little attention to mutual fund fees (Choi, Laibson \& Madrian, 2005; 2011).

Several behavioural biases, such as framing effects and investment menu design, can negatively affect retirees' ability to make optimal portfolio composition and asset allocation decisions. Retirement savings plan investment choices are affected by the numbering and order of the investment options presented (see Tapia and Yermo, 2007, for a review). Investors also react differently depending on what type of information is presented to them - for example, whether or not the long-term or short-term results are presented to them (Benartzi \& Thaler, 2004; Benartzi \& Thaler, 2007). Survey evidence from the US and the Netherlands shows unstable preferences in relation to asset allocation (Benartzi \& Thaler, 2007). The typical respondent opted for a conservative portfolio, but, when shown the long-run returns on his/her portfolio 
and a portfolio containing more stocks, there was a tendency for respondents to switch to a riskier portfolio (Van Rooij et al., 2007). Systematic empirical evidence indicates that people naively tend to extrapolate current returns trends into the future, and this excessive extrapolation influences annuity choices (Benartzi, 2001; Agnew et al., 2010). These problems are particularly acute when financial literacy is low and where households have not gained longterm experience in making financial decisions (Holzmann, 2010).

\subsubsection{A critical evaluation of the policy proposal}

It is clear from the above discussion that this policy principle is well grounded in the behavioural economics literature, which indicates that many people fail to make sensible and informed financial choices. The policy proposal to limit choice in the income decumulation phase will potentially go a long way in addressing the problems of the high cost structures of living annuities and the consequent potential misselling of living annuities.

However, limiting choice will not be sufficient to address the problem of unsustainable high withdrawal rates. Based on the principle that consumer motives and knowledge should inform policy remedies (Black, 2006), the reasons for choosing a high drawdown rate should inform the nature of the policy remedy. Rational reasons for selecting high drawdown rates based on anecdotal evidence include where the beneficiary does not expect or require the accumulated retirement income to last a lifetime. Examples include where the retirement money from one family member could be used to invest in the education of younger members, who would in return support the retiree in later life (National Treasury, 2012; Dempsey, 2014). Another example concerns low-income workers who choose to buy living annuities and withdraw their assets quickly in order to qualify for the old age grant at a later date. In such a case, limiting choices on withdrawal rates might not benefit the retiree.

Where the reasons for high drawdown rates is a lack of self-control and present bias, or inadequate knowledge about the impact of withdrawal rates on long-term income, limiting choices on withdrawal rates should be completed by specific policy remedies, including appropriate and focused financial education to protect retirees from themselves. However, when inadequate retirement savings is the reason for high initial drawdown rates, limiting choice and financial education will not solve the problem. Given the current complete lack of systematic evidence on the strategies and motives underlying these drawdown rates, it is difficult to design appropriate policy remedies. Thus, more research on retirement income decisions in South Africa is urgently needed.

\subsection{Increasing the degree of automation in the retirement process}

The main policy proposal to increase automation in the retirement income process is that all retirement funds should be required to choose a default product into which all retirees must be enrolled (National Treasury, 2012:36).

\subsubsection{The rationale for the policy proposal: Choice, procrastination and information overload}

The proposed default option is broadly in line with behavioural finance findings on financial choice, procrastination, and information overload. Most individuals are affected by inertia or procrastination (they put off a decision until tomorrow) when faced with decisions regarding investment choices. Furthermore, too many investment choices can cause information overload. 
In turn, this may lead to the empirically observed tendency of contribution plan participants making choices based on the "path of least resistance" or choosing the default option (Madrian \& Shea, 2001).

The general concept of choice architecture and specifically the provision of default options is a well-established principle in the behavioural finance literature to improve retirement income security. The provision of a default option is mainly motivated by the empirically observed pervasiveness of the largely positive effect of providing a default option on retirement savings decisions (DellaVigna, 2009; Beshears et al., 2008; lyengar et al., 2006).

Choice architecture is based on the idea that defaults can be set to achieve desired outcomes by exploiting status-quo bias and inertia. Choice architecture can be classified as non-binding standards that steer individuals towards organising their affairs in a certain way, but without imposing an outright mandate (Thaler \& Sunstein, 2008). The non-binding nature of choice architecture is potentially a major benefit that makes it preferable to mandatory requirements, which have less flexibility and may inhibit mutually beneficial transactions.

In addition to the automatic enrolment version of default options, more sophisticated applications of the default principle have been developed. These include lifecycle funds that offer a "one-stop solution" to asset allocation. The younger the investor, the higher his or her exposure to riskier asset classes such as equities. In particular, asset allocation funds enhance equity market participation among lower-paid employees (Portabera et al., 2011).

\subsubsection{A critical evaluation of the policy proposal}

Despite these potential advantages, product design and choice architecture are themselves inherently limited, especially when the determination of the "right choice" is not infallible. Default options are not generally optimised for the individual. Less financially literate workers are most vulnerable in a situation where the "right" default is ambiguous, since they tend to interpret defaults as advice (Madrian \& Shea, 2001) and are less likely to exercise their right to opt out appropriately if the default proves unsuitable.

Even the more sophisticated applications of default options, such as lifecycle funds, do not offer a foolproof solution to the asset allocation problem in retirement planning. The available empirical evidence (Arnott, 2012; Schleef \& Eisinger, 2011) suggests that lifecycle asset allocation strategies do not provide adequate portfolio risk protection in terms of maximising the probability of reaching a particular wealth accumulation target.

Thus, the major message from the literature is that default options are an incomplete solution to sub-optimal decision-making in retirement. Retirees need to understand the different options available to them, even if these options are simplified in order to achieve this. Agnew et al. (2011) found that individuals with below-average knowledge find the investment decision overwhelming, regardless of the plan's features. Providing a default option can be made more efficient by financial education that develops consumer familiarity with the specific form types.

Thus, a more promising policy alternative might be to recognise financial education as an essential complementary policy tool to make choice architecture work. It is important to ensure that people understand the implications of the default option, as well as the implications of opting out (Antolín, 2010). Furthermore, behavioural 'mistakes' might be symptomatic of a deep lack of understanding of the nature of the investment decision process (Tapia \& Yermo, 2007). Researchers have found that participants make more optimal decisions when they understand 
their retirement plan features (Choi et al., 2005; Chan \& Stevens, 2008). In fact, financial illiteracy and perverse behavioural biases are two related aspects of the same overall problem: poor household financial decision-making. Behavioural biases may affect behaviour more strongly when people lack the necessary knowledge and skills to make an informed decision. Without the necessary financial capability, investors may even fail to consider the factors that should affect their decisions.

South African policy-makers do acknowledge the important role of financial education in reaching better retirement decisions. However, the emphasis seems to be on general financial education that starts in primary school (National Treasury, 2011:60). The need is for specific education, with the aim of providing investors and retirees with an adequate understanding of investment concepts, and facilitating the formation of realistic expectations of the behaviour of the capital markets (Glass, 2000).

\subsection{Increasing the degree of longevity protection for most retirees}

\subsubsection{The rationale for the policy proposal}

As noted, National Treasury is concerned about the fact that fewer individuals are choosing to buy conventional life annuities - the only products offering longevity protection. Investors in living annuities run the risk that they will outlive their assets. The stated rationale for the policy proposal to encourage investment in conventional annuities is to provide a secure lifetime income, while no investment decisions or financial advice are required. The ability of conventional annuities to provide a secure income for life is widely acknowledged in the literature. For example, Benartzi, Previtero and Thaler (2011) describe conventional annuities as a product that allows investors to increase consumption and eliminate risk at the same time, and, thus, an annuity strictly dominates the investment alternative. In the South African context, Lodhia and Swanepoel (2012) use breakeven analysis to show that by design a conventional annuity is better equipped to provide an income for life than a living annuity. Conventional annuities make it easier for retirees to deal with uncertainty, and help solve the cognitively difficult task of deciding how fast to draw down their wealth (MacDonald et al., 2012; Babbell, 2008). International recommendations are that households should use $40 \%$ to $80 \%$ of their income to buy a conventional annuity, especially households lacking a defined benefit pension plan. Still, annuity aversion is an international phenomenon, and is referred to as the annuity puzzle in the literature (Dushi \& Webb, 2004).

An understanding of the reasons for annuity aversion might be useful in informing policy as to the most appropriate policy option to encourage investment in conventional annuities.

There are several reasons for annuity aversion described in the literature, although several weaknesses remain in our understanding of annuity aversion (MacDonald et al., 2012). A low life expectation due to ill health is the most obvious rational reason. Survey evidence suggests that opposition to annuitisation is most strongly expressed by those with lower income, education and health - characteristics associated with lower life expectancies (Gardner \& Wadsworth, 2004). In general, most people prefer liquid assets and are unwilling to "lock up" their money. Anecdotal evidence suggests that these are important considerations for South African retirees, and are often used as an explanation for the popularity of living annuities with financial advisors and the financial industry in particular.

Limited understanding of annuities can also lead to annuity aversion. The unpopularity of 
conventional annuities relative to living annuities in South Africa is partly ascribed to a lack of proper insight into the product design, especially the often-overlooked benefits of mortality pooling embedded in a guaranteed annuity (Lodhia \& Swanepoel, 2012).

People tend fundamentally to undervalue the appeal of a lifetime annuity. Warner and Pletter (2001) found that $92 \%$ of US defence force personnel chose a lump sum over having an underlying guaranteed interest rate that was nearly three times the prevailing rate in the capital market, and approximately twice as high as the expected return on risky assets at that time. Collectively, they forfeited an estimated total of $\$ 1.7$ billion in economic value. Survey evidence from Canada (BMO, 2012) suggests that people simply do not understand the trade-offs involved in choosing between income withdrawal products.

The behavioural economics literature also offers explanations for the annuity puzzle. Framing issues can be particularly powerful because of the complicated nature of the product. Brown, Kling, Mullainathan and Wrobel (2008) found that the vast majority of individuals prefer an annuity over alternative products when the question is framed in terms of consumption, while the majority prefer non-annuitised products when the question is presented in terms of riskand-return ("investment") decision. They hypothesise that when consumers think in terms of consumption, annuities are viewed as valuable insurance, whereas when consumers think in terms of investment risk and return, the annuity becomes a risky asset, because the payoffs depend on an uncertain date of death. This explanation is in line with the phenomenon of loss aversion (Tversky \& Kahneman, 1992). Thus, a key issue is whether a retiree considers the purchase of an annuity as a cost (and thus a loss) or as an "investment" (Hu \& Scott, 2007).

The Greenwald et al. (2006) survey also revealed that numerous participants have the feeling that they can do a "better job" investing than the insurance companies can. The accompanying view that life annuities are good for people who do not want to manage their own assets or who are financially unsophisticated might be suggestive of overconfidence.

\subsubsection{A critical evaluation of the policy proposal}

The policy proposal to encourage longevity protection by encouraging conventional annuities is well grounded in the retirement income literature and seems to be appropriate for most South Africans, especially in light of the fact that a defined contribution retirement plan is the sole source of retirement income for most South African retirees. However, the current policy proposals do not recognise the importance of understanding the motives behind the lack of annuitisation. The behavioural economics literature offers valuable insights in this regard. If the lack of annuitisation is driven by misinformation and other behavioural biases, rather than rational and informed insight, focused financial education programmes or setting policies that encourage annuitisation (Brown, 2009) would be the appropriate policy remedy.

A focused programme of financial education should form an integral part of a behaviourally informed policy response aimed at encouraging people to buy appropriate income drawdown products. This is because the choice of an appropriate drawdown product involves a trade-off between choice, risks and costs that hinges on the retiree's various circumstances and preferences (Portebera, Venit \& Wise, 2011). Living annuities might indeed be the appropriate choice for certain households. Retirees need more information and understanding to be able to make appropriate decisions. A second factor that points to the importance of financial education is the strong indications in the literature that people underestimate the value of 
conventional annuities, because they do not understand the nature of the product and thus the potential advantages of such a product.

Once it is accepted that conventional annuities are the better alternative for the majority of South Africans, an appropriate policy response would be to evaluate the different policy approaches to encourage annuitisation. These options range from simply mandating annuitisation to nudging retirees towards conventional annuities, as well as promoting product innovation leading to "better" annuities.

A behaviourally informed approach will recognise that the mandating approach presents a potential negative impact on the behaviour of investors and the incentives of financial industry agents. This includes the opportunity of annuity providers to take advantage of the mandatory purchase requirement, such as by raising prices (0rzag, 2000). The removal of individual choice is another potential drawback, especially for those who would find it sub-optimal to annuitise personal savings owing to personal circumstances. Consequently, people could, in fact, be discouraged by an annuity mandate to save, since it could reduce their lifetime economic welfare.

If, however, an avoidance of annuitisation proves to be driven by fundamental preferences, the findings might suggest new financial products that would better meet the needs of retirees. The most obvious application of the "better annuity" option is to make sure that annuity pricing accurately reflects the risk of the individual. National Treasury (2012:9) acknowledges that this might be an issue, since conventional annuities are priced explicitly only by age and sex in South Africa. Several suggestions have been made to increase the flexibility of conventional annuities. These include reversible annuities that allow the annuity decision to be reversible to some extent.

Wang and Young (2010) and Babbel (2008) describe existing annuities in the USA that provide more flexibility for new policyholders to lock in at current interest rates while preserving the ability to benefit from interest rate improvements over a specified period of time and the option to pay for an annuity over time, thus spreading out the underlying interest rate risk.

The National Treasury discussion document also contains elements of providing "better annuities". A sequential hybrid annuity is proposed that starts off as phased-withdrawal products, but then shifts individuals into conventional life annuities as they get older. The biggest innovation is the possibility of postponing (or phasing in) the purchase of life annuities until individuals are in their mid-seventies, cutting the costs of providing longevity insurance, and reducing the consequences to individuals of the variability of annuity rates. Furthermore, they would permit investment in risky assets, allowing greater flexibility to members in the early years of their retirement. Such an innovation might also address the concern that the policy proposal focuses on the fact that conventional annuities offer a secure lifetime income (National Treasury, 2012) without consideration of the adequacy of this income, especially in the current low interest rate environment.

\subsection{Policy proposal: Limiting the need for financial advice and financial intermediation}

The rationale for this proposal is that high fees on living annuities create scope for misselling (National Treasury 2012:5). Misselling creates significant potential for consumer detriment. National Treasury (2012:18) estimates that in most cases charges on living annuities would 
consume $20 \%$ of the policy's value over its life. Research in the UK confirms that "charges are the most important determinant of the size of the final pension" (Harrison, Blake \& Dowd 2012). The main message from the academic literature is that these concerns are valid. There is a considerable body of systematic empirical evidence indicating that the structure of investment products, rather than their suitability, drives their sale to customers. Also, financial advice is often lacking in quality (Mullainath, Noeth \& Schoar, 2012).

The unambiguous findings of the literature on the impact of financial advice on consumer wellbeing warrant a more nuanced policy remedy than simply reducing the need for financial advice. Research grounded in the traditional economics paradigm focuses on the moral hazard problem and information asymmetries between financial advisors and their customers (Hackethal, Haliassos \& Jappelli, 2012). In markets with inattentive consumers and shrouded attributes (Gabaix \& Laibson, 2006), perverse situations with high fees can persist as bona fide economic equilibria when there are enough naive consumers.

The behavioural economics literature supports the view that some people are naïve about how conflicts of interest affect the quality of advice. Some experimental evidence suggests that many participants are willing to follow advice rather blindly and even knowledge about the potential conflict of interests between them and their advisors does not always seem to make them sufficiently wary (Oehler, Kohlert, \& Jungermann, 2010). Empirical studies also indicate that investors have difficulties comprehending and rationalising conflict-of-interest disclosures.

There is a body of literature that emphasises the potentially positive impact of professional, customised financial advice. Dutkiewicz, Levin, and Dukhi (2007) build a strong case that good financial advice could improve investor welfare by pointing out heuristics and providing simple advice such as starting to save early (Hackethal, Haliassos \& Jappelli, 2012). Guidance in terms of appropriate asset allocation and risk diversification decisions, especially among less sophisticated households, can also add value.

Given the potential for consumer detriment arising from inappropriate financial advice, several policy interventions aimed at regulating the relationship between investors and advisors are highlighted in the academic literature. These policy measures can be classified in terms of the following framework (Inderst, 2010):

1. Policies that aim at reducing the need for advice, either by improving the quality of information or sophistication of consumers or by reducing the (perceived) complexity of products and services;

2. Policies that ensure that the quality of advice improves, for example by requiring that advisors meet higher standards of qualification or that they are given appropriate incentives to gather information and provide unbiased advice; and

3. Policies that target the way consumers deal with advice - for instance, through the provision of information about advisors' incentives.

The proposals by National Treasury concentrate on the first option: limiting the need for advice. A behaviourally informed approach would be to take into account the fact that consumers generally find retirement-related decisions confusing, and, consequently, their willingness and ability to make complicated decumulation decisions without the assistance of a financial advisor are limited (Bunt et al., 2006). The most promising policy initiatives would thus aim to mitigate the risk of exposing unsophisticated investors to manipulation while still allowing 
access to advice. Given that there is extensive regulation of the investor's advisor relationship in South Africa, mainly through FAIS legislation and the TCF (treat customers fairly) regulatory framework, better enforcement of the existing regulatory framework is another potential policy approach.

Effective disclosure of the impact of high living annuity fees on living annuities has been suggested by some industry commentators as a potential policy approach (Nathan, 2012). FAIS legislation has elaborate requirements in terms of fee disclosure, as well as disclosure of potential conflict of interest created by broker compensation. There is no available empirical evidence on the impacts of these requirements, but the international empirical evidence on the impact of fee disclosure on investor behaviour is not very encouraging. Consumers tend to show a robust insensitivity to the features and fees associated with financial products of all types. Disclosure of broker compensation tends to increase confusion and effectively alienate consumers from all backgrounds, leading to sub-optimal choices (Lacko \& Pappalardo, 2004). Disclosure requirements might also have a perverse impact on the incentives of firms and advisors. Risk-averse financial institutions might opt to provide complicated documents that are designed to provide legal protection, but detract from consumer understanding.

Providing information about fees in a way that participants will effectively utilise and improve their decision-making remains a key policy challenge. Behavioural economics research suggests several avenues for improving disclosure, such as mandating simplified disclosure information in clear, non-technical language that emphasises the saliency of key facts and information that is likely to be overlooked by consumers or shrouded by firms, such as the impact of recurring fees on living annuities benefits. The available empirical evidence on the impact of such "customerfriendly" disclosure requirements is not very encouraging. Choi, Laibson and Madrian (2011) reveal that a one-page summary sheet which showed how to calculate the impact of fees on portfolio value had only modest positive effects on altering portfolio allocations. Beshears et al. (2010) found that while simplified disclosures significantly improved satisfaction and reduced time on task, actual choices were not much affected.

A promising alternative is to test and refine disclosure statements through an iterative process consisting of a series of in-depth interviews with consumers with different rounds of testing where disclosure statements can be adjusted, based on consumer understanding. Such an approach was followed by Macro International (2008) on behalf of the Federal Board of Governors. Thus the involvement of consumers in the design and implementation of policy remedies can increase the possibility of improved policy impact (Macro International, 2010).

\section{CONCLUSIONS}

South Africans face several challenges in securing financial security in retirement. The importance of appropriate financial decisions in the decumulation phase of retirement is increasingly recognised as an important determinant of retirement financial security. This article provides an integrated view of the factors that shape retirement income withdrawal decisions.

This review reveals that very little is known about how South Africans make decisions about retirement income products. What we do know is that they prefer living annuities to conventional annuities, that the relatively high fees on living annuities significantly erode retirement benefits and that a substantial part of living annuitants withdraw more than the seemingly arbitrarily 
chosen sustainable rate of $5 \%$ of the balance of their living annuity balance as an annual income. Policy proposals are based on the presumption that retirees in general make suboptimal financial choices, that conventional annuities that offer longevity protection are the appropriate retirement income product for the majority of South Africans and that the popularity of living annuities is mainly driven by misselling, and that financial advisors are motivated by the relatively high commissions on these products. Based on this, the main proposed policy approach is to limit the choices available to retirees, encourage longevity protection and limit the use of financial advice through the mandating of a default option.

A critical evaluation of these proposals revealed that they are broadly in line with the results of the previous research findings, which indicate that many people fail to make sensible and informed financial choices, that financial advisors can exploit the naivety of investors and that there is considerable scope for misselling of retirement income products.

The use of default options and encouraging the use of conventional annuities to provide longevity protection are recommendations to enhance optimal income withdrawal decisions. However, a critical evaluation based on the behaviourally informed approach to financial regulation approach revealed that these are at best a partial solution. Even if the decisionmaking environment is simplified, retirees still need a basic knowledge of retirement planning, specific features of retirement products, as well as aspects related to realistic return expectations. The available evidence suggests that the majority of South Africans do not have this basic knowledge. A more promising policy alternative is thus to recognise financial education as an essential complementary policy tool in making choice architecture work.

The policy proposal to limit the need for financial advice is a more controversial approach to enhancing optimal income withdrawal decisions. The literature suggests that, although there is considerable scope for misselling through financial advisors, financial advice also offers several potential advantages and that few people are willing or able to make retirement income product decisions without financial advice. Thus, a more appropriate policy approach would aim at mitigating the impact of inappropriate advice, while still providing access to financial advice. Focused financial education that aims at enabling retirees to recognise appropriate sound advice can play a major role in this regard.

The results of the current research suggest that the problem of unsophisticated consumers who must make several challenging choices using complicated products is a multi-faceted one that requires multiple policy remedies. Challenges and problems in retirement security need to be addressed holistically and require a broader discussion of the state of South Africa's household finances and our general levels of financial literacy.

To build policies on solid foundations, further theoretical, empirical, and experimental work must be done on the retirement security of South Africans. In general, more research is needed to provide insights into how South Africans actually make financial decisions in the income withdrawal phase. This would illuminate key areas where more could be done to inform, educate, and deepen people's understanding of optimal retirement income withdrawal decisions. It would also contribute to more informed policy remedies. The nature of the choices made by retirees who decide to invest in living annuities and especially how these choices are influenced by financial advisors is one area where more research is of critical importance. Active cooperation and coordination among different regulators is needed. 


\section{LIST OF REFERENCES}

Agnew, J., Anderson, L. \& Szykman, L. (2010). An Experimental Study of the Effect of Prior Market Experience on Annuitization and Equity Allocations. Working Paper.

Agnew, J.R., Szykman, L.R., Utkus, S.P. \& Young, J.A. (2011). What people know about target-date funds: survey and focus group evidence. Financial Security Project, Boston College. Working paper series no.FSP2011-2.

Alexander Forbes (2013). Manager watch survey: Annual Retirement fund survey.

http://www.alexanderforbes.co.za/business/Publications.aspx

Antolín, P. (2010). Private Pensions and the Financial Crisis: How to ensure adequate retirement income from defined contribution pension plans? Financial Market Trends, Vol. 2009, No. 2

Arnott, R. (2012). The Glidepath illusion. Research affiliates. Available from: www.researchaffiliates.com. Accessed 12 January 2013.

Association for Savings and Investment South Africa (ASISA). 2012. The 2012 Living Annuities Survey (Online). Available: http://www.asisa.org.za. Accessed 30 April 2013.

Atkinson, A. \& Messy, F. (2012). Measuring Financial Literacy Results of the OECD/International Network on Financial Education (INFE) Pilot Study. OECD. Paris.

Babbel, D.F. (2008). Lifetime Income for Women: A Financial Economist's Perspective. Wharton Financial Institutions Centre Policy Brief: Personal Finance.

Barr, M.S, Mullainathan, S. \& Shafir, દ. (2008). Behaviorally Informed Financial Services Regulation. New America Foundation White Paper.

Benartzi, S, Previtero, A. \& Thaler, R.H. (2011). Annuitization Puzzles. Journal of Economic Perspectives, 25(4), pp. 143-64.

Benartzi, S. \& Thaler, R. (2004). Save More Tomorrow: Using Behavioral Economics to Increase Employee Saving, Journal of Political Economy, 112(1), pp. 164-187.

Benartzi, S. \& Thaler, R.H. (2007). Heuristics and Biases in Retirement Savings Behavior. The Journal of Economic Perspectives, 21, pp. 81-104.

Benartzi, S. (2001). "Excessive Extrapolation and the Allocation of 401 (k) Accounts to Company Stock." Journal of Finance, 56 (5), pp. 1747-1764.

Beshears, J., Choi, J.J., Laibson, D. \& Madrian, B.C. (2008). How are preferences revealed? Journal of Public Economics, 92(8-9), pp. 1787-1794.

Black, J. (2006). Involving consumers in securities regulation. Prepared for the Taskforce to Modernize Securities Regulation in Canada.

BMO Retirement Report Institute. (2012). Retirement income planning: Can we have our cake and eat it too? February.

Brown, J. (2009). Understanding the Role of Annuities in Retirement Planning, 178-206, in Overcoming the Saving Slump, ( $\varepsilon \mathrm{d}$ : Annamaria Lusardi), Chicago: University of Chicago Press.

Brown, J.R., Kling, J.R., Mullainathan, S. \& Wrobel, M.V. (2008). Why Don't People Insure Late-Life Consumption? A Framing Explanation of the Under-Annuitization Puzzle. American Economic Review, 98(2), pp. 304-309. 
Bunt, K., Adams, L., Koroglu, Z. \& O'Donnell, દ. (2006). Pensions and pension reform.DWP Research Report 357.

Chan, S. \& Stevens, A.H. (2008). What You Don't Know Can't Help You: Pension Knowledge and Retirement Decision-Making, The Review of Economics and Statistics, MIT Press, 90(2), pp. 253-266.

Choi, J.J., Laibson, D. \& Madrian, B.C. (2005). \$100 Bills on the Sidewalk: Suboptimal Saving in 401 (k) Plans. NBER Working Paper 11554.

Choi, J.J., Laibson, D. \& Madrian, B.C. (2011). Why Does the Law of One Price Fail? An Experiment on Index Mutual Funds.

Collins, D. (2007). Financial education, Social security and retirement funding: Perspectives from the Financial Diaries September 2007.

Cronqvist, H. \& Thaler, R.H. (2004). Design Choices in Privatized Social-Security Systems: Learning from the Swedish Experience. American Economic Review, 94(2), pp. 424-428.

DellaVigna, S. (2009). Psychology and Economics: evidence from the field. Journal of Economic Literature, 47(2), pp. 315-372.

Dempsey, P.(2014). Living annuity policyholders opt for lower income to preserve capital. Available from http://www.asisa.org.za/index.php/en/66-media-release/187-living-annuity-policyholdersopt-for-lower-income-to-preserve-capital. Accessed on 11 December 2014.

Dushi, I., \& Webb, A. (2004). Household Annuitization Decisions: Simulations and Empirical Analyses. Journal of Pension Economics and Finance, 3(2), pp. 109-143.

Dutkiewicz, C., Levin, S. \& Dukhi, A. (2007). The value of financial advice: it's not just about the cost. Actuarial Society of South Africa Convention,

Fear, J. (2008). Choice overload: Australians coping with financial decisions. Discussion Paper no. 99, The Australia Institute, Canberra

Gabaix, X. \& Laibson, D. (2006). Shrouded Attributes, Consumer Myopia, and Information Suppression in Competitive Markets. Quarterly Journal of Economics, 121(2), pp. 505-540.

Gardner, J. and Wadsworth, M. (2004). Who Would Buy an Annuity? An Empirical Investigation (March 2004). Watson Wyatt Technical Paper No. 2004-4. Available at SSRN:

http://ssrn.com/abstract=892767 or http://dx.doi.org/10.2139/ssrn.892767. Accessed on 17 July 2013.

Glass, R.D. (2000). Investment Education or Advice? That's the Wrong Question to Ask! Employee Benefits Journal, 25(2). International Foundation of Employee Benefits. June 2000.

Greenwald, M., Bryck, S.A. \& Sondergeld, દ.T. (2006). Spending and investing in retirement: is there a strategy. Report for LIMRA International and the Society of Actuaries.

Hackethal, A., Haliassos, M. \& Jappelli, T. (2012). Financial Advisors: A Case of Babysitters? Journal of Banking and Finance, 36(2), pp. 509-524

Harrison, D. Blake, K. and Dowd, K. (2012). Caveat Venditor: the Brave New World of Auto-Enrolment Should Be Governed by the Principle of Seller Not Buyer Beware." Pensions Institute Report, October.

Holzmann, R. (2010). Bringing Financial Literacy and Education to Low and Middle Income Countries: The Need to Review, Adjust, and Extend Current Wisdom. IZA Discussion Papers 5114, Institute for the Study of Labor (IZA). 
Hu, W-Y., \& Scott, J.S. (2007). Behavioral Obstacles in the Annuity Market. Financial Analysts Journal, 63(6), pp. 71-82.

Inderst, R. (2010). Consumer Protection and the Role of Advice in the Market for Retail Financial Services. Journal of Institutional and Theoretical Economics (JITE), 167(2011), pp. 4-21.

lyengar, S. \& Kamenica, દ. (2006). The Psychological Costs of Ever Increasing Choice: A Fallback to the Sure Bet. Working paper, Graduate School of Business, Management Department, Columbia University.

Jappelli, T. (2010). Economic literacy: an international comparison. The Economic Journal, 120, F429F451. Doi: 10.1111/j.1468-0297.2010.02397.

Lacko, J.M. \& Pappalardo, J.K. (2004). The Effect of Mortgage Broker Compensation Disclosures on Consumers and Competition: A Controlled Experiment. Federal Trade Commission Bureau of Economics Staff Report. Available at http://www.ftc.gov/sites/default/files/documents/reports/effectmortgage-broker compensation-disclosures-consumers-and-competition-controlled experiment/\$030123mortgagesummary.pdf. (Accessed 15 January 2012).

Lodhia, M. \& Swanepoel, J. (2012). Living versus guaranteed annuities: in search of a sustainable retirement income. Presented at the Actuarial Society of South Africa's 2012 Convention 16-17 October 2012, Cape Town International Convention Centre.

MacDonald, B-J., Jones, B., Morrison, R.J., Brown, R.L., \& M. Hardy. (2012). Research and Reality $-A$ Literature Review on Drawing Down Retirement Savings. Society of Actuaries. Available from: http://www.soa.org/research/research-projects/pension/default.aspx. Accessed 13 November 2012.

Macro International Inc. (2008), Design and Testing of Effective Truth in Lending Disclosures: Findings from Experimental Study (December 15), submitted to the Board of Governors of the Federal Reserve System, www.federalreserve.gov/newsevents/press/bcreg/bcreg20081218a8.pdf. (Accessed 15 January 2012).

Madrian, B.C. \& Shea, D.F. (2001). The Power of Suggestion: Inertia in 401(k) Participation and Savings Behavior, in: Puarterly Journal of Economics, 116(4), pp. 1149-1187.

Merton, R.C. (2003). Thoughts on the Future: Theory and Practice in Investment Management. Financial Analysts Journal, 59(1), pp. 17-23.

Mullainath, S., Noeth, M. \& Schoar, A. (2012). The Market for Financial Advice: An Audit Study. NBER Working Paper No. 17929.

Nathan, S. (2012). FAIS has failed, not living annuities. 10X Publications. Available at http://www.10x.co.za/publications/fais-has-failed-not-living-annuities/. (Accessed 15 December 2012).

National Treasury. (2004). Pension fund reform: a discussion paper. December, Pretoria.

National Treasury. (2012). Discussion paper B: Enabling a better income in retirement. September, Pretoria.

National Treasury. (2012). Strengthening retirement savings: An overview of proposals announced in the 2012 Budget.

National Treasury. (2011). A safer financial sector to serve South Africa better

Oehler, A. Kohlert, D. \& Jungermann, H. (editors). (2010). The Quality of Financial Investment Advice for Private Investors: Problems in the Advice Process and Potential Solutions. Statement by the Scientific Advisory Board on Consumer and Food Policies at the Federal Ministry of Food, Agriculture and Consumer Protection (BMELV). 
Orszag, M.J. (2000). Annuities: The Problems. Presented at NAPF Annual Conference, 11-12 May 2000.

Poterba, J., Venti, S. \& Wise, D. (2011). "The Composition and Drawdown of Wealth in Retirement," Journal of Economic Perspectives, American Economic Association, 25(4), pp. 95-118.

Schleef, H.J., \& Eisinger, R.M. (2011). Life-cycle Funds: International Diversification, Reverse Glide Paths, and Portfolio Risk. Journal of Financial Planning, 24(1), pp. 50-58.

Tapia, W. \& Yermo, J. (2007). Implications of Behavioural Economics for Mandatory Individual Account Pension Systems. OECD Working Papers on Insurance and Private Pensions, No. 11, 0ECD Publishing.

Thaler, R.H. \& Sunstein, C.R. (2008). Nudge: Improving decisions about health, wealth, and happiness. Yale University Press.

Tversky, A. and Kahneman, D. (1992). "Advances in Prospect Theory: Cumulative Representation of Uncertainty." Journal of Risk and Uncertainty, 5(4), pp. 297-323.

Van Rooij, M., Lusardi, A. \& Alessie, R. (2009). Financial literacy and Retirement planning in the Netherlands. De Nederlandse Bank Working paper 231/2009. Amsterdam.

Wang, T. \& Young, V.R. (2010). Optimal Reversible Annuities to Minimize the Probability of Lifetime Ruin. Quantitative Finance Papers, 1001.4270., 2010.

Warner, J. \& Pletter, S. (2001). The personal discount rate: Evidence from military downsizing programs. American Economic Review, 91(1), pp. 33-53. 
De Beer 